\title{
Detection of infectious bronchitis-like virus isolated from psittacines at breeding facilities
}

\author{
GANITA K. SURYAMAN ${ }^{1}$, RETNO D. SOEJOEDONO ${ }^{2}$, OKTI NADIA POETRI ${ }^{2}$, AGUS SETIYONO ${ }^{1}$, \\ EKOWATI HANDHARYANI, ${ }^{1, \bullet}$ \\ ${ }^{1}$ Pathology Division, Department of Clinic Reproduction and Pathology, Faculty of Veterinary Medicine, Institut Pertanian Bogor. Jl. Agatis, Kampus \\ IPB Dramaga, Bogor 16680, West Java, Indonesia. Tel./fax.: +62-251-8421807, ^email: ekowatieko@apps.ipb.ac.id. \\ ${ }^{2}$ Medical Microbiology Division, Department of Animal Disease and Veterinary Public Health, Faculty of Veterinary Medicine, Institut Pertanian Bogor. \\ Jl. Agatis, Kampus IPB Dramaga, Bogor 16680, West Java, Indonesia
}

Manuscript received: 24 March 2021. Revision accepted: 21 September 2021.

\begin{abstract}
Suryaman GK, Soejoedono RD, Poetri ON, Setiyono A, Handharyani E. 2021. Detection of infectious bronchitis-like virus isolated from psittacines at breeding facilities. Biodiversitas 22: 4261-4265. Captive breeding of parrots has been carried out in Indonesia to fulfill market demand for pets and support conservation efforts. However, there is limited information about Infectious Bronchitis Virus (IBV) in captive parrots. Therefore, this study examines IBV virus in psittacines and observes the pathological changes in inoculated chicken embryos. Cloacal swabs were obtained from 31 psittacine birds consisting of 15 sulfur-crested cockatoos (Cacatua sulphurea), 10 palm cockatoos (Probosciger aterrimus), two blue and yellow macaws (Ara ararauna), two green-winged macaws (Ara chloropterus), and two scarlet macaws (Ara macao). Swabs were also injected for 9 days to obtain specific pathogen-free (SPF) embryonated chicken eggs, and allantoic fluids were collected after 7 days. The residual cloacal swabs and allantoic fluid samples were tested for IBV by reverse transcription polymerase chain reaction (RT-PCR) targeting spike 1 glycoprotein (S1) and nucleoprotein (N) gene by primer set XCE2+/XCE2- and IBVN+/IBVN-, while the harvested inoculated embryos were examined for histopathological lesions by hematoxylin-eosin staining. Three and one allantoic fluid of $C$. sulphurea and $P$. aterrimus respectively were found positive for IBV by primer set IBVN+IBVN-. However, there was no significant difference in the inoculated embryo's gross anatomy, and the slight histopathological changes observed were not caused by the virus. Therefore, it is unclear whether the IB-like virus causes clinical disease manifestation in both Psittacine species or the chicken embryo. This is the first study carried out on IB-like viruses for both species.
\end{abstract}

Keywords: Infectious Bronchitis Virus, N gene, Psittacine, RT PCR, S1 gene

Abbreviations: IBV: Infectious Bronchitis Virus, RT-PCR: Reverse Transcriptase Polymerase Chain Reaction, SPF: Specific Pathogen Free

\section{INTRODUCTION}

Indonesia's bird diversity is among the highest in the world but is threatened by deforestation and illegal capture for trades (Jepson et al. 2008). In 2005, a study on 5 big cities in Sumatra and Bali reported that $60.2 \%$ of pets owned by the population were birds, and more than half kept and sold in the Indonesian market were wild-caught (Jepson and Ladle 2005). Although most of the birds observed in the household are songbirds, the report stated that 50,590 wild-caught parrots are acquired per year and kept as pets. Given the popularity and the lack of law enforcement, a softer approach to this environmental problem is achieved by encouraging captive-bred birds into the community (Jepson et al. 2008; Jepson and Ladle 2009). Therefore, the breeding program is an important factor for conservation.

Captive breeding of several Parrot species such as the Sulphur-crested cockatoo (Cacatua sulphurea) and palm cockatoo (Probosciger aterrimus) have been conducted to fulfill market demand. However, the problem of low reproductivity is still prevalent in the field. This is most likely due to a lack of knowledge about the reproductive biology of birds in captivity or the danger of sickness. Information about parrot diseases in Indonesia is limited. Meanwhile, one of several diseases that threaten the reproductive ability of birds is the Infectious Bronchitis Virus (IBV). It is a widespread virus and causes economic loss in the poultry industry worldwide (Bande et al. 2016). Infectious Bronchitis Virus mainly attacks the respiratory system, spreads to the kidney and reproductive system, with differing severity depending on the strain. With the wide variety of serotypes that are not often crossprotective, IBV remains a problem in the poultry industry despite rigorous vaccination programs (de Wit et al. 2010; Bande et al. 2016).

Moreover, evidence of IBV in several species other than chicken (Gallus gallus domesticus) has been reported (Hughes et al. 2009; Sabarinath et al. 2011; Miłek and Blicharz-Domańska 2018), including and Eclectus parrot (Eclectus roratus) (Suryaman et al. 2019). However, studies on pathological changes caused by IBV-like viruses in psittacines are still limited. This is caused by the rare cases and the conservation law that makes conducting experimental studies, especially on protected psittacines, difficult. 
This study attempts to determine the probability of IBV occurrence in many captive-bred psittacine species, given the importance of captive-bred birds and the dearth of knowledge on psittacine viral infections at captive breeding facilities.

\section{MATERIALS AND METHODS}

\section{Cloacal swab sample}

Given the importance of disease information for psittacine conservation, this study was conducted with samples from several breeding facilities from 2016 to 2018. Thirty-one cloacal swab samples were obtained from psittacine birds consisting of 15 sulfur-crested cockatoos (Cacatua sulphurea), 10 palm cockatoos (Probosciger aterrimus), two blue and yellow macaws (Ara ararauna), two green-winged macaws (Ara chloropterus), and two scarlet macaws (Ara macao). None of the birds showed signs of illness and appeared healthy. These birds belong to two private breeding facilities in Jakarta and Bogor, Indonesia, and had never been vaccinated. The Psittacine breeding facilities separated the birds per pair in cages in different buildings divided by species. The swab samples were kept in a viral transport medium consisting of Phosphate Buffer Saline (PBS) solution added with antibiotics (Penicillin 10,000 [IU]/mL and Streptomycin 10 $\mathrm{mg} / \mathrm{mL}$ ) according to OIE guidelines for IBV (OIE 2018). Meanwhile, this study was carried out according to the ethics guidelines of the ethical committee, Faculty of Veterinary Medicine, IPB university, with the number 058/KEH/SKE/IV/2017.

\section{Virus isolation}

The pathological aspect is essential to understand the pathogenesis of viral infection in the host. Meanwhile, viral pathology studies in exotic animals are often challenging to perform because the conservation status of these animals does not allow experimentation with pathological conditions. On the other hand, psittacines are valuable birds with a vulnerable group. Therefore, this study aims to examine the pathology of virus obtained from the chicken embryo after inoculation of swab sample materials.

Cloacal swab suspensions were mixed with antibiotics (penicillin $1000[\mathrm{IU}] / \mathrm{mL}$, streptomycin $10 \mathrm{mg} / \mathrm{mL}$ ) and inoculated via allantoic cavity into two SPF embryonated chicken eggs aged 9-days up to $0.2 \mathrm{~mL}$ each, and incubated at $36^{\circ} \mathrm{C}$. Furthermore, controls inoculated with sterile phosphate buffer saline (PBS) were used while allantoic fluids were collected on day 4, and embryos were harvested on day 7 post-inoculation. The embryos were separated for histopathological examination and stored in formaldehyde until trimming, while allantoic fluids were stored at $-20^{\circ} \mathrm{C}$ for immediate use (Fereidouni ey al. 2012) and $-80^{\circ} \mathrm{C}$ for extended storage.

\section{Viral RNA extraction}

Viral RNAs were extracted from swab and allantoic fluid samples using RNAeasy Mini Kit (Qiagen) for total RNA based on the manufacturer's instructions. The RNAs were diluted in $30 \mu \mathrm{L}$ of RNAase-free water for immediate use or stored at $-20^{\circ} \mathrm{C}$ for short-term storage (Wu et al. 2011).

\section{Amplification}

RT PCR amplification was performed using Bioline One-Step RT PCR kit (Bioline, UK) with 2 primer pairs namely IBVN+/IBVN- primer set $(\mathrm{IBVN}+$ sequence 5'GAAGAAAACCAGTCCCAGATGCTTGG-3' and IBVNsequence 5'-GTTGGAATAGTGCGCTTGCAATACCG-3') targeted $\mathrm{N}$ gene of IBV, as well as XCE2+/XCE2- primer set (XCE2+ sequence 5'-CACTGGTAATTTTTCAGATGG3' and XCE2- sequence 5'-CCTCTATAAACACCCTTACA3') targeted $\mathrm{S} 1$ gene of IBV. The thermal profile for RT PCR was as follows; reverse transcription at $45^{\circ} \mathrm{C}$ for 20 minutes (min), initial denaturation at $95^{\circ} \mathrm{C}$ for $1 \mathrm{~min}$, with 40 cycles (denaturation $95^{\circ} \mathrm{C}$ for 15 seconds (sec); annealing at $58^{\circ} \mathrm{C}$ and $30 \mathrm{sec}$ for partial $\mathrm{N}$ (Handberg et al. 1999) and $50^{\circ} \mathrm{C}$ for $30 \mathrm{sec}$ for partial S1 gene (Jahantigh et al. 2013); extension at $72^{\circ} \mathrm{C}$ for $30 \mathrm{sec}$, followed by a final extension at $72^{\circ} \mathrm{C}$ for $7 \mathrm{~min}$. Meanwhile, the primer set XCE2+/XCE2- for S1 gene HVR3 has been tested in a preliminary study stage on 6 vaccines available in Indonesia (H120, 4/91, CR388, H52, 233A, and 1-96) with a positive result. The amplicon length produced for IBVN+/IBVN- was 453 bp (Handberg et al. 1999) and 466 bp for XCE2+/XCE2- (Jahantigh et al. 2013).

\section{Histopathology examination}

Embryos that were harvested on day 7 after inoculation were trimmed and made into a paraffin block. The samples were dehydrated in graded alcohol, stained with Hematoxylin Eosin (HE), and then rehydrated with xylene. The slides were observed with $20 x$ and $40 x$ objective lens magnification using a light microscope.

\section{RESULTS AND DISCUSSION}

\section{RT PCR examination result}

Four out of thirty-one allantoic samples were positive for IBV $\mathrm{N}$ gene, but none were positive for IBV S1 gene (Table 1). Three allantoic fluid samples of $C$. sulphurea, namely Indonesia/Cs8/16, Indonesia/Cs9/16, and Indonesia/Cs10/16, and one allantoic fluid sample of $P$. aterrimus, Indonesia/ $\mathrm{Pa} 4 / 16$, were positive for IBV by partial $\mathrm{N}$ gene primer.

\section{Embryo histopathology examination}

The gross pathology of the embryos is presented in Figure 1. There were no significant differences in the gross pathology between control and test samples. In addition, stunting, clubbing, or bleeding was not observed in the gross pathology of all embryos. The histopathological result of the embryos showed slight changes in the lungs of samples compared to normal control. The lung lumen of the samples appeared less expanded and defined compared to the control. However, this slight change was found in all sample embryos, and samples showed positive RT PCR results. 
Table 1. RT PCR examination result. $\mathrm{N}$ column is the result of RT PCR amplified by primer set IBVN-/IBVN+ targeting N gene of IBV while $\mathrm{S} 1$ column is the result of RT PCR by primer set XCE2-/XCE2+ targeting S1 gene of IBV

\begin{tabular}{|c|c|c|c|c|c|}
\hline \multirow[t]{2}{*}{ Isolate } & \multirow[t]{2}{*}{ Species } & \multicolumn{2}{|c|}{$\begin{array}{c}\text { Cloacal } \\
\text { Swab }\end{array}$} & \multicolumn{2}{|c|}{$\begin{array}{c}\text { Allantoic } \\
\text { Fluid }\end{array}$} \\
\hline & & $\mathbf{N}$ & S1 & $\mathbf{N}$ & S1 \\
\hline Indonesia/Cs1/16 & Cacatua sulphurea & - & - & - & - \\
\hline Indonesia/Cs2/16 & Cacatua sulphurea & - & - & - & - \\
\hline Indonesia/Cs3/16 & Cacatua sulphurea & - & - & - & - \\
\hline Indonesia/Cs4/16 & Cacatua sulphurea & - & - & - & - \\
\hline Indonesia/Cs5/16 & Cacatua sulphurea & - & - & - & - \\
\hline Indonesia/Cs6/16 & Cacatua sulphurea & - & - & - & - \\
\hline Indonesia/Cs7/16 & Cacatua sulphurea & - & - & - & - \\
\hline Indonesia/Cs8/16 & Cacatua sulphurea & - & - & + & - \\
\hline Indonesia/Cs9/16 & Cacatua sulphurea & - & - & + & - \\
\hline Indonesia/Cs10/16 & Cacatua sulphurea & - & - & + & - \\
\hline Indonesia/CsKR1/16 & Cacatua sulphurea & - & - & - & - \\
\hline Indonesia/CsKR2/16 & Cacatua sulphurea & - & - & - & - \\
\hline Indonesia/CsKR3/16 & Cacatua sulphurea & - & - & - & - \\
\hline Indonesia/CsKR4/16 & Cacatua sulphurea & - & - & - & - \\
\hline Indonesia/Pa1/16 & Probosciger aterrimus & - & - & - & - \\
\hline Indonesia/Pa2/16 & Probosciger aterrimus & - & - & - & - \\
\hline Indonesia/Pa3/16 & Probosciger aterrimus & - & - & - & - \\
\hline Indonesia/Pa4/16 & Probosciger aterrimus & - & - & + & - \\
\hline Indonesia/Pa5/16 & Probosciger aterrimus & - & - & - & - \\
\hline Indonesia/Pa6/16 & Probosciger aterrimus & - & - & - & - \\
\hline Indonesia/Pa7/16 & Probosciger aterrimus & - & - & - & - \\
\hline Indonesia/Pa8/16 & Probosciger aterrimus & - & - & - & - \\
\hline Indonesia/Pa9/16 & Probosciger aterrimus & - & - & - & - \\
\hline Indonesia/Pa10/16 & Probosciger aterrimus & - & - & - & - \\
\hline Indonesia/Aa1/16 & Ara ararauna & - & - & - & - \\
\hline Indonesia/Aa2/16 & Ara ararauna & - & - & - & - \\
\hline Indonesia/Ac1/16 & Ara chloropterus & - & - & - & - \\
\hline Indonesia/Ac2/16 & Ara chloropterus & - & - & - & - \\
\hline Indonesia/Am1/16 & Ara macao & - & - & - & - \\
\hline Indonesia/Am $2 / 16$ & Ara macao & - & - & - & - \\
\hline
\end{tabular}

Note: The + mark means positive result while - mark means a negative result

\section{Discussion}

Infectious Bronchitis Virus is the most studied virus of the Avian Coronavirus. Although IBV studies on freeliving birds have been reported, there is still limited information about IBV incidence in birds other than chickens. Gough et al. (2006) isolated Avian Coronavirus from Psittacine bird, the Amazon green-cheeked parrot (Amazona viridigenalis). However, the coronavirus found was genetically different from IBV based on the polymerase gene sequence. Recently, Suryaman et al. (2019) isolated Avian Coronavirus from the Psittacine bird, Eclectus parrot, sampled in 2016. Based on the S1 gene nucleotide sequence, the coronavirus found was homologous to IBV.

The RT-PCR results showed that three isolates of Sulphur-crested cockatoo and one isolate of palm Cockatoos were positive for $\mathrm{N}$ gene of IBV, but none were positive for S1 gene of IBV. The primers in PCR only captured genes that matched the sequences. Hence, differences in gene sequence might prevent unmatched primers from attaching to the nucleotide strands and give
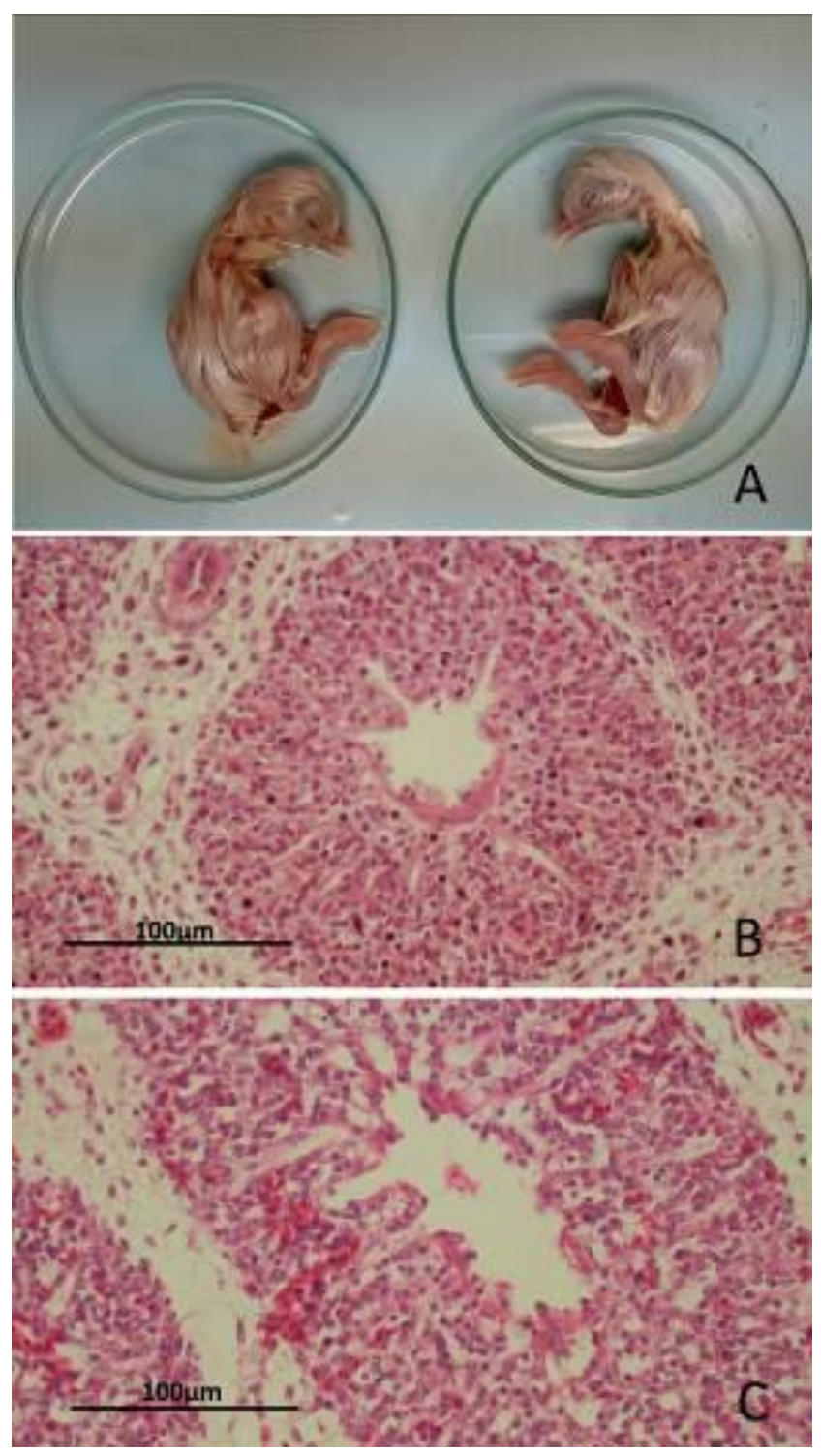

Figure 1. (A) No difference was detected from the gross pathology of day 18 chicken embryo infected by swab sample (left) with control (right). However, there was a slight difference in the lung histopathology as shown by HE staining for positive sample Indonesia/Pa4/16 (B) and control chicken embryo (C) in day 18 chicken embryo. Still, the difference was found in all embryos inoculated by all samples. Hence, the virus does not solely cause the difference in this study.

PCR test a negative result. Fan et al. (2019) stated that N is the most genetically conserved structural gene of IB virus while $\mathrm{S} 1$ is the most varied. Therefore, $\mathrm{N}$ gene primers are more sensitive in capturing IBV, given that it does not undergo significant change compared to other structural genes. This probably explains why four isolates positive for $\mathrm{N}$ gene were negative for S1 gene. Another reason is that the nucleotide sequences did not match the primers used. The S1 primers used targeted HVR3 of IB virus (Setiawaty et al. 2019). Hence, there might be changes in this part of the S1 gene. In a preliminary study, the primer had previously been tested on 6 different vaccine strains in 
Indonesia, and all showed positive reactions. This indicates that the primer captured vaccine strains by the HVR3 region. Meanwhile, the negative result suggested that the nucleotide sections of the virus at the primer region were different from the vaccines used in Indonesia.

The S1 gene is highly variable, meanwhile, differences in the nucleotide sequences within the hypervariable regions tend to prevent specific primers from detecting the different strains. With the great diversity of S1 gene, several primers are used across the globe to target various variable sites (Valastro et al. 2016). Although the detection of IB virus by S1 primers is challenging, gene sequencing is still regarded as the basis of IB virus classification (Valastro et al. 2016). Turkey coronavirus (TCoV), one of Avian Coronavirus in Gammacoronavirus, is genetically similar to IBV and only falls into different clusters in a phylogenetic tree constructed based on S1 gene (Chen et al. 2015). Due to the inability to capture the S1 gene, the virus found in this study was not classified. Therefore, it was concluded that the virus found in this study was an IBVlike virus.

All RT-PCR positive results were from allantoic fluid and none from swab samples. This indicates that the amount of the virus isolated from these birds was low. Hence, the virus needs to be propagated in the embryonated chicken egg to a detectable level. Furthermore, none of IBV infection characteristics such as stunting or clubbing appeared, and no significant difference in gross anatomy was found between the samples and control. In this study, only a one-time passage into an embryonated egg was performed. Still, based on Jackwood dan de Wit (2019), characteristics such as stunting and curling appear after several passages provided the embryonated eggs are propagated from field samples. Based on histopathology observation, slight differences were found in the lungs of sample embryos compared to control. The lung lumen in the sample embryos appeared to be filled with cells and was less defined than the control. However, these slight differences were found on all samples, not just from samples that showed positive results for the $\mathrm{N}$ gene of IBV. Therefore, it was not clear whether the slight difference in the lungs was due to the virus infection. An explanation for this occurrence is that IB-like virus at a low amount does not cause significant pathological changes to chicken embryos and a lack of adaptability due to the lack of passage in the embryonated chicken egg.

All birds sampled in this study appeared to be clinically healthy, but reproductive difficulties were reported for the Psittacine birds at the breeding facilities, especially $P$. aterrimus. Probosciger aterrimus, which has a relatively long lifetime, has a slow reproductive ability even in captivity (Heinsohn et al. 2009). A study that measured egg quality in the Haugh unit on layer flocks related to IBV in Australia found that IBV is one of the potential risk factors for eggs with poor Haugh units (Hewson et al. 2014). Furthermore, eggs of IBV infected chicken appeared to be malformed with thin albumin (Bande et al. 2016). A decrease in egg quality was observed after the virus had ceased replicating (Hewson et al. 2014) and after clinical respiratory symptoms had stopped. Egg evaluation in
Psittacine is more complex than layers poultry due to comparatively low laying frequency. Although no clinical disease was found, the infection might be subclinical. Therefore, further studies on the pathogenesis of the virus are needed for a better understanding. However, necropsies or provocative tests are difficult to perform considering the conservation status of the birds sampled. Aside from infections, non-infectious reasons such as mating behaviors also contribute to the breeding problem.

The IB-like virus is frequently found in wild birds from Europe, the Caribbean, Madagascar, and Australia (Hughes et al. 2009; Sabarinath et al. 2011; Domanska-Blicharz et al. 2014; de Sales Lima et al. 2015). Spillover from poultry farms due to improper management of waste is one of the causes of viral infection in birds (Hughes et al. 2009; Devlin et al. 2016; Rohaim et al. 2017). This danger might also extend to non-Galliform captive birds, as illustrated in this study. The efforts to defend the poultry against IBV include vaccinations. However, due to the limited information on the genotype and serotype of the circulating virus and the data on the effect of its effectiveness, vaccination of IBV in the Psittacine birds is still up for debate. Moreover, there was no apparent health impact of IB-like virus in the Psittacine species examined in this study. However, better biosecurity is recommended, while further studies are required to elucidate better the virulence and the nature of the IB-like virus found in Psittacines.

\section{ACKNOWLEDGEMENTS}

The authors are grateful to the Ministry of Research Technology and Higher Education of the Republic of Indonesia for funding this study through PMDSU (Pendidikan Magister menuju Doktor untuk Sarjana Unggul) and PKPI (Peningkatan Kualitas Publikasi Internasional) grants.

\section{REFERENCES}

Bande F, Arshad SS, Omar AR, Bejo MH, Abubakar MS, Abba Y. 2016. Pathogenesis and diagnostic approaches of avian infectious bronchitis. Adv Virol 2016: 1-11. DOI: 10.1155/2016/4621659.

Chen Y-N, Wu CC, Lin TL. 2015. Turkey Coronavirus: An updated review. Taiwan Vet J 41(1): 1-10. DOI: $10.1142 / \mathrm{S} 1682648515300014$.

de Sales Lima FE, Gil P, Pedrono M, Minet C, Kwiatek O, Campos FS, Spilki FR, Roehe PM, Franco AC, Maminiaina OF, Albina E, de Almeida RS. 2015. Diverse gammacoronaviruses detected in wild birds from Madagascar. Eur J Wildl Res 61(4): 635-639. DOI: 10.1142/S1682648515300014.

de Wit JJ, Cook JKA, van der Heijden HMJF. 2010. Infectious bronchitis virus in asia, africa, australia and latin america - history, current situation and control measures. Rev Bras de Cienc 12(2): 97-106. DOI: 10.1590/s1516-635x2010000200004.

Devlin JM, Vaz PK, Coppo MJC, Browning GF. 2016. Impacts of poultry vaccination on viruses of wild bird. Curr Opin Virol 19: 23-29. DOI: 10.1016/j.coviro.2016.06.007.

Domanska-Blicharz K, Jacukowicz A, Lisowska A, Wyrostek K, Minta Z. 2014. Detection and molecular characterization of infectious bronchitis-like viruses in wild bird populations. Avian Pathol 43(5): 406-413. DOI: 10.1080/03079457.2014.949619.

Fan W, Tang N, Dong Z, Chen J, Zhang W, Zhao C, He Y, Li M, Wu C, Wei T, Huang T, Mo M, Wei P. 2019. Genetic analysis of avian 
coronavirus infectious bronchitis virus in yellow chickens in Southern China over the past decade: Revealing the changes of genetic diversity, dominant genotypes, and selection pressure. Viruses 11(10): 898. DOI: $10.3390 / \mathrm{v} 11100898$

Fereidouni SR, Globig A, Starick E, Harder TC. 2012. Effect of swab matrix, storage time, and temperature on detection of avian influenza virus RNA in swab samples. Avian Dis 56(4 Suppl): 955-958. DOI: 10.1637/10146-033012-ResNote.1.

Gough RE, Drury SE, Culver F, Britton P, Cavanagh D. 2006. Isolation of a coronavirus from a green-cheeked Amazon parrot (Amazona viridigenalis Cassin). Avian Pathol 35(2): 122-126. DOI: 10.1080/03079450600597733.

Handberg KJ, Nielsen OL, Pedersen MW, Jørgensen PH. 1999. Detection and strain differentiation of infectious bronchitis virus in tracheal tissues from experimentally infected chickens by reverse transcription-polymerase chain reaction. Comparison with an immunohistochemical technique. Avian Pathol 28: 327-335. DOI: 10.1080/03079459994579.

Heinsohn R, Zeriga T, Murphy S, Igag P, Legge S, MacK AL. 2009. Do Palm Cockatoos (Probosciger aterrimus) have long enough lifespans to support their low reproductive success? Emu 109: 183-191. DOI: 10.1071/MU08053.

Hewson K, Robertson T, Steer P, Devlin JM, Noormohammadi A, Ignjatović J. 2014. Assessment of the potential relationship between egg quality and infectious bronchitis virus infection in Australian layer flocks. Aust Vet J 92(4): 132-138. DOI: 10.1111/avj.12156.

Hughes LA, Savage C, Naylor C, Bennett M, Chantrey J, Jones R. 2009. Genetically diverse coronaviruses in wild bird populations of northern England. Emerg Infect Dis 15(7): 1091-1094. DOI: 10.3201/eid1507.090067.

Jackwood MW, de Wit S. 2019. Infectious Bronchitis. In: Diseases of Poultry: Fourteenth Edition. John Wiley \& Sons, Inc., USA 14: 167188. DOI: $10.1002 / 9781119421481 . c h 4$.

Jahantigh M, Salari S, Hedayati M. 2013. Detection of infectious bronchitis virus serotypes by reverse transcription polymerase chain reaction in broiler chickens. SpringerPlus 2(1): 36-36. DOI: $10.1186 / 2193-1801-2-36$.
Jepson P, Ladle RJ. 2005. Bird-keeping in Indonesia: Conservation impacts and the potential for substitution-based conservation responses. Oryx 39(4): 442-448. DOI: 10.1017/S0030605305001110.

Jepson P, Ladle RJ. 2009. Governing bird-keeping in Java and Bali: Evidence from a household survey. Oryx 43(3): 364-374. DOI: 10.1017/S0030605309990251

Jepson P, Prana M, Sujatnika, Amama F. 2008. Developing a certification system for captive-bred birds in Indonesia. TRAFFIC Bulletin 2(1): 7-9.

Miłek J, Blicharz-Domańska K. 2018. Coronaviruses in avian speciesreview with focus on epidemiology and diagnosis in wild birds. J Vet Res 62(3): 249-255. DOI: 10.2478/jvetres-2018-0035.

Rohaim MA, El Naggar RF, Helal AM, Hussein HA, Munir M. 2017. Reverse spillover of avian viral vaccine strains from domesticated poultry to wild birds. Vaccine 35(28): 3523-3527. DOI: 10.1016/j.vaccine.2017.05.033.

Sabarinath A, Sabarinath GP, Tiwari KP, Kumthekar SM, Thomas D, Sharma RN. 2011. Seroprevalence of infectious bronchitis virus in birds of Grenada. Int J Poult Sci 10(4): 266-268. DOI: 10.3923/ijps.2011.266.268.

Setiawaty R, Soejoedono RD, Poetri ON. 2019. Genetic characterization of $\mathrm{S} 1$ gene of infectious bronchitis virus isolated from commercial poultry flocks in West Java, Indonesia. Vet World 12(2): 231-235. DOI: 10.14202/vetworld.2019.231-235.

Suryaman GK, Soejoedono RD, Setiyono A, Poetri ON, Handharyani E. 2019. Isolation and characterization of avian coronavirus from healthy Eclectus parrots (Eclectus roratus) from Indonesia. Vet World 12(11): 1797-1805. DOI: 10.14202/vetworld.2019.1797-1805.

Valastro V, Holmes EC, Britton P, Fusaro A, Jackwood MW, Cattoli G, Monne I. 2016. S1 gene-based phylogeny of infectious bronchitis virus: An attempt to harmonize virus classification. Infect Genet Evol 39: 349-364. DOI: 10.1016/j.meegid.2016.02.015.

World Organization for Animal Health (OIE). 2018. Avian Infectious Bronchitis. In: OIE Terrestrial Manual 2018. Paris, France.

Wu J, Kim L, Huang C, Anekella B. 2011. Stability of extracted RNA at various storage temperatures and through multiple freeze-thaw cycles. Annual Meeting; International Society for Biological and Environmental Repositories, Arlington, Virginia, USA, May 16-18 2011. 